\title{
Conservation Risk Assessment for Managing Plant Collection of a Botanic Gardens in Indonesia
}

\author{
Reni Lestari ${ }^{1 *}$ \\ ${ }^{1}$ Research Center for Plant Conservation And Botanic Garden, Indonesian Institute of Sciences, Bogor, Indonesia \\ ${ }^{*}$ Corresponding author. Email: reni_naa@yahoo.com; reni001@lipi.go.id
}

\begin{abstract}
Botanic Garden (BG) is one of ex situ Plant Conservation Institution that manages documented collections for conservation, research, education, tourism and ecosystem services purposes. There are many processes for plants to become garden's collection, from collecting the plants from their original habitat until displaying at the garden. The aim of this study is to identify risks of plant collections management of the botanic gardens, with accordance to the processes or procedures of plant collections in the garden in Bogor/Indonesian experience, as well as the effort to reduce the risks for prevention and mitigation. The identified risks of plant collections management of a botanic gardens are specific and could be different from one to other BGs. From 16 identified risks related with plant collection procedure at Bogor BG, 13 of those are on the level of Likelihood 3 or $50 \%$ probability or above and the impact level of the risks higher than 3 or significant. The control and action plan to prevent the risks are very urgent to be conducted immediately. The prevention of the risks even become most priority for the highest level of probability and impact, which in relation to human safety and loss of plant collection/database. In general, existing control of the identified risks has been prepared or available including the staff, procedure, equipment, tools and supervision. Many risks should be preventive by more communication, coordination, work appropriately and as procedure. Therefore, strict control and supervision are still needed to be conducted with more detail and routine.
\end{abstract}

Keywords—risk assessment, Botanic Gardens, plant collection, control action, mitigation

\section{INTRODUCTION}

Botanic Gardens (BG) is an ex situ conservation institution that manage documented of plant collections for conservation, research, education, tourism and ecosystem services purposes $[1,2]$. In term of conserving plant species, there are many activities and procedures in collecting and handling plants to become garden's collection, starting from gathering the plant materials from their original habitat until displaying at the garden. The garden plant collections are then displayed in the garden according to the taxonomical classification, bioregion, thematic or combination of those patterns [1]. Globally, some related intentions regarding plant collections of the BG, that listed at the Global Strategy for Plant Conservation (GSPC) of CBD-UN for the year 2011-2020 are targets 8 and 14 [3]. Target 8 of GSPC mentioned that "At least $75 \%$ of threatened plant species in ex situ collections, preferably in the country of origin, and at least $20 \%$ available for recovery and restoration programs". Whereas target 14 of GSPC explains that "The importance of plant diversity and the need for its conservation incorporated into communication, education and public awareness programs" [3].

At this time, there are as many as 43 botanic gardens have been established or still in the process of establishment in more than 17 provinces in Indonesia. Four botanic gardens are owned by central government (Indonesian Institute of Sciences/LIPI), i.e. Bogor BG (BBG), Cibodas BG, Purwodadi BG and Eka Karya Bali BG. On the other hand, the regional gardens or non-central government botanic gardens could be owned by a province, a district or a city government, a University or even by individual person. Globally, there are currently 1775 botanic gardens and arboreta in 148 countries around the world with many more under construction or being planned [4].

According to [1], BBG has a duty as advisor and mentor or supervisor of the process in establishing new botanic gardens in Indonesia. Each BG has specific theme on their plant collections. Theme of plant collections of the BG under central government are Humid lowland plants for Bogor BG, Humid highland plants for Cibodas BG, Dry lowland plants Purwodadi BG, and Dry highland plants for Eka Karya Bali BG. Some example themes of plant collection of the regional botanic gardens in Indonesia are Sumatera medicinal and wetlands flora for Sumatera Selatan $\mathrm{BG}$, Indonesian timber plants for Balikpapan BG, and Wallacean region flora for Massenrempulu Enrekang BG.

In general, an organization of a $B G$ institution in Indonesia comprises of at least 2 Division, i.e. 1) Division 
of Ex situ plant conservation and 2) Division of Administration. Under Division of Ex situ plant conservation, there are several Sub Divisions or Units such as 1.a) Nursery Unit, 1.b) Registration Unit, 1.c) Collection Maintenance Unit, 1.d) Seed Bank Unit, 1.e) Herbarium Unit, 1.f) Reintroduction Unit, and 1.g) Compost Unit. Plant collection management in a BG usually involves Nursery Unit, Registration Unit, and Collection Maintenance Unit.

In conducting the works, a BG has standard of procedure, such as international standard procedure ISO or other kind of management procedure. Bogor BG has been certified of ISO 9001:2008 since 2012 and ISO 9001:2015 since 2016 until 2017. However due to the change of its organization in 2018, Bogor BG still adopt the standard procedure as well as other rules according to the Government Regulation. BGs institution usually has also Management Plan, including Risk Management [5, 6].

The high value of plant collection in the BGs have many risks in term of its conservation management that very crucial to be identified and assessed. The aim of this study is to identify risks of plant collections management of the botanic gardens, with accordance to the processes or procedures of plant collections in the garden in Bogor/Indonesian experience, as well as the effort to reduce the risks for prevention and mitigation.

\section{Materials ANd MethodS}

The risk assessment in this study generally is based on ISO 31000 [7]. The first step to be conducted in the study is to identify the risk in relation with BG's plant collection, which mostly are gathered from internal data of the Bogor BG [5]. The study is continued by searching the sources and impacts of the identified risks. Based on the processes and Units related to plant collection of the Bogor BG. The risks of the garden collections are going to be divided into three, i.e. (1) Acclimatization and maintenance of the plant seedling collection at the garden's nursery, (2) Database of the plant collection at Registration Unit of the garden, and (3) Display of the collection at the garden. Next step is to estimate the impact of the risks and the magnitude or level of the identified risks. The last step is to analyze, control, prevention, mitigate, and action plan in respond to all of identified risks.

\section{RESULTS}

BG's plant collections mostly gathered from the original plant habitat, through exploration and collection actions throughout Indonesia, beside resulted from donation or exchange activities. All data of the plant's material are recorded from the beginning of the collection activity. Plant material handling, packing and transport to the BG from the natural habitat of plant are very crucial due to critical condition of plant material during the period and also during acclimatization at the nursery of BG. Data of plant collection in the nursery and continued during display at the garden is registered into database at Registration Unit. Many activities are also conducted to maintain plant collection in the garden displaying in the garden at the Collection Maintenance Unit.

\section{Risks during acclimatization and maintenance of the plant} material at the Nursery Unit

The type of plant material receiving at the Nursery Unit could be mature fruit or seed, seedlings, cutting branches, whole minor size plant, and fern spore. The handling of plant material depends on the type and plant species of the material collected. For example, seeds are then sowing at bench with sand or other media after being processed/cleaned from fruit pulp. The material then get access number from the Registration Unit with all data from the field at original habitat is attached. The maintenance of plant material at Nursery Unit is conducted until the plants are ready to be planted at the garden. The identified risks, internal and external sources of risks as well as its impacts of risks of all of those procedures at the nursery are 1.a until 1.d as follows:

a. Plant material could not be handled and damage condition, which due to lack of communication between staff of the nursery and staff who conducted exploration (usually at remote and far away areas) and also due to the receiving of the plant material at the nursery at holiday time. Therefore, the plant material could not be handled just after arrive at the nursery

b. Plant material could not grow well after being handled, which due to damage condition before handled or too long-time during transport or the inappropriate material packing. The plant material is becoming die after that.

c. Data of the plant material is disorganized due to less rechecked or the removal of the plant label or not being input at the database that cause lack of the plant material data and information.

d. Plant materials grow not optimal caused by do not maintained appropriately due to lack of media/facility, lack of human resources, climate/disaster condition, pest/disease or the staff are not inappropriate in maintaining the plant such as in watering the plant. Thus, the plants are becoming wilt or drying or not in healthy condition

\section{Risks of the plant collection database at Registration Unit} of the garden

There are many data item regarding plant collection in the BG, starting from the data of original habitat (name of location, latitude, longitude, habitat condition, etc.), the plant material type, the plant material name (Greek name (species/genus/family), local name), the use of the plant by local people, name and number of the collector, type of handling in the field etc., date the collection is received at the nursery, access number of the collection, type of handling in the nursery, date to be planted in the garden, location in the garden, type of maintenance in the garden, when the collection is flowering/fruiting until the collection is dead.

The risks of those processes, the internal and external sources and its impacts are 2.a until 2.f as follows:

a. Data is not complete due to lack of information data menu at database, data entry is not complete, wrong data entry or the data information from the plant collector is not available from the plant collector 
b. Data is not yet registered due to no being processed as the procedure, no report from staff at nursery/garden, no complete data is available or due to external source such as drying plant condition, wrong report of the location of the plant or attacked by animal. Therefore, the plant is not registered as the garden's collection

c. The change of plant name data has not yet been recorded due to no report regarding the name change from the identificatory or researchers to the Registration unit, data has not be untried,

d. Data is lost or damage due to the attack of computer virus or building fired or computer stealing. This cause lost and unavailable of the data

e. Information regarding the data of plant collection is not valid due to officer negligence/human error

f. The map of the plant collection in the garden is not accurate, due to no report of relocation, officer negligence/human error/wrong data report at the field, the equipment is broken or lost

\section{Risks of plant collection at Maintenance Unit}

The identified risks during displaying and maintenance of plant collection at the garden including internal and external sources of risks as well as impacts are 3.a until 3.f as follows:

a. The plant condition is not healthy therefore, the plant growth is not optimal. This is due to lack of fertilizer, location of the plant is not suitable, lack of pest and disease control, human resource is not competent, environment and climate factor, attacked by pest and disease.

b. The plant condition is drying due to lack of water, attacked by pest and disease, climate/long dry season, lack of water resource, lightening attack, damaged by human and animal

c. The plant is died which mean the reduction of the garden collection. This is due to no pest and disease control, lack of watering, damaged by human and animal, attacked by lightening.

d. The plant/tree is fell down/ the branches are broken which can danger the visitors and the garden staff, vehicle/car, equipment, and other plant collection. This is caused by plant inspection is not detail, handling damaged plant or tree pruning is too late or not precise, climate/big wind or rain, unstable soil condition, age of plant

e. Visitors or staff of the garden get accident caused by broken branches or fall down of the tree at the garden. This risk due to the dead plant collection has not been pruned or handled.

f. Accident of the staff during working, which could danger the staff and visitors. This due to less skilled worker, job security tools are not used, the maintenance of the equipment is less thorough/routine, equipment condition is not working properly, equipment is not adequate in amount/specific, the surrounding safety area is not as much as necessary.

\section{The Risk Analysis, Map and Priority for Control and Action Plan}

The risk analysis involves consideration of the causes and source of risk, their positive and negative consequences, and the likelihood that those consequences can occur [7]. The risk analysis for this study used quantitative level of the probability as well as the level of impact from 1 until 5. It is very important to set a priority and plan the control action as soon as possible after identified and analysis or map of risks have been set up. Among all of the identified risks, it can be sorted from the highest into the lowest priority. There are 5 levels of risks found as priority to be controlled, and mitigated.

The result of the analysis could be seen in Table 1 in the form of the risk map. The matrix $5 \times 5$ consist of Likelihood and Impact, with both are ranged from 1 until 5. The highest level of risk in the plant collection management of the garden with Likelihood value 4 (likely) and impact 5 (catastrophic) is 3.e. (Visitors or staff of the garden get accident caused by broken branches or fall down of the tree), continued by second level of risks with Likelihood 4 (likely) and impact 4 (Major) of 3.d (The tree is fell down or branches are broken) and 2.b. (Data of plant collection is not registered). The third level of risk with Likelihood 3 (possible) and Impact 4 (Major) comprised of 3.f (Accident of the staff during working), 3.c. (The plant is died), 1.a. (Plant material from exploration could not be handled in the nursery and damage condition), 1.b. (Plant material could not grow well after being handled), 2.d. (Data is lost or damage), 1.c. (Data of the plant material is disorganized), 2.a. (Data is not complete), 2.c. (The change of plant name data has not yet been recorded), 2.f. (The map of the plant collection in the garden is not accurate), 3.a. (The plant condition is not healthy). The fourth level with Likelihood 2 (Unlikely) and Impact 3 (Significant), i.e. 2.e. (Information regarding the data of plant collection is not valid) and 3.b. (The plant condition is drying). The lowest level with Likelihood 3 (possible) and Impact 3 (Significant) is 1.d. (Plant materials grow not optimal) (Table 1). 
TABLE 1. THE RISK MAP OF THE PROCEDURES OF PLANT COLLECTION AT BOTANIC GARDEN

\begin{tabular}{|c|c|c|c|c|c|c|c|}
\hline \multirow{2}{*}{\multicolumn{3}{|c|}{ RISKS ANALYSIS MATRIX 5 X 5}} & \multicolumn{5}{|c|}{ IMPACT } \\
\hline & & & 1 & 2 & 3 & 4 & 5 \\
\hline Description & Probability & Likelihood & Negligible & Minor & Significant & Major & Catastropic \\
\hline Very Likely & $90 \%$ & 5 & & & & & \\
\hline Likely & $70 \%$ & 4 & & & & $2 . b, 3 d$ & 3.e. \\
\hline Possible & $50 \%$ & 3 & & & 1.d & $\begin{array}{c}\text { 1.a, 1.b., 1.c, 2.a, 2.c, 2.d, } \\
\text { 2.f. 3.a, 3.c, 3.f }\end{array}$ & \\
\hline Unlikely & $30 \%$ & 2 & & & & 2.e, 3.b & \\
\hline Very Unlikely & $10 \%$ & 1 & & & & & \\
\hline
\end{tabular}

\section{DISCUSSION}

\section{A. Identified and Assessment of Risks}

The identified risk to be explained in the results of this study is coming out from internal data of Bogor BG. The garden is established more than 200 year ago and many of its plant collection are ancient, which plant health condition are very different as compared with collection of other BGs in Indonesia, especially Regional BG that established less than 10 years ago. Each BG has specific condition or different condition than other BG, therefore their risks will be different as compared to those of Bogor BG. It is very important and urgent for all BGs to conduct also risk identification, assessment and mitigation.

In general, the identified risks at Bogor BG mostly with level of Likelihood 3 and Impact level 4 or major. This mean after being assessed, the control and action to prevent the risks are very urgent to be conducted immediately. The prevention of the risks even become most priority for the highest level of probability and impact, which in relation to human safety.

The risks at the Nursery Unit of 1.a. and 1.b. are very closed related with exploration and collection activity at original habitat of the plant material. Therefore, the risks of the exploration activity should also be identified and continued to be assessed, and also identified mitigation strategies. The communication between staff that conducted exploration and staff at Nursery Unit that handle the plant material should close in contact and communication regarding the delivery of plant material to the nursery.

The risk for individual living collection of the BG to be assessed, which is still very limited according to [8] is the collection that introduce of most environmental weeds listed by IUCN as among the worst invasive species worldwide. This is very important for BG to take into account of their plant collection and also their prospective collections, which include invasive plant species. To tackle those biological invasions, involve public outreach, information sharing and capacity building, which are priorities to prevent the problems of the past occurring in the future [8]. There is the weed risk assessment (WRA) that evaluates each potential plant introduction using many questions that encompass a wide range of factors such as the biological characteristics of the plant, its environmental tolerance, any characteristics that may render it directly harmful to humans or agriculture, and its introduction history in other areas $[9,10]$.
The identified risks should include all of the plant collection in the garden, including collections in the greenhouse or shade house. The collection used to be conserved at the greenhouse are orchid, Nepenthes, Araceae, Ferns, etc. The capacity and capability of BG staff as well as the control or supervision of all works at the garden related with plant collection should be developed. Therefore, the risk due to human error, staff/officer negligence or disorganization of works could be deleted.

The result of the risk analysis could become input for risk evaluation and decision on whether the risks are going to be treated with the most appropriate treatment strategies and methods. The priority of the controlled action plans is then set up according the value to be analyzed as resulted at Table 1 .

\section{B. Risk Control, Prevention and Mitigation}

After the identified risks are assessed, the existing control and gap should be explained and further followed by identifying possible prevention and mitigation strategies. The example of existing gap are the works is not done as standard procedure, nature condition, data safety is insufficient, lack of risk knowledge or awareness, less coordination between Unit, less of supportive data, less effort of work. The prevention and mitigation of the risks are going to be explained according to the Unit of the BG (Appendix 1).

In general, existing control of the identified risks has been prepared or available including the staff, procedure, equipment, tools and supervision (Appendix 1). However, many risks should be preventive by more communication, coordination, work appropriately and as procedure. Therefore, strict control and supervision are still needed to be conducted in more detail and routine.

There are actually many other risks which not only related specifically with the maintenance procedure of plant collection of the BG. Risk Management of Christchurch BG in New Zealand explained that the garden will identify and isolate and minimize risk to people, property, and assets and provide for a safe work environment [6]. Some examples of risk of Christchurch BG are physical injury, failure of machinery or equipment, breach of security, fraud, litigation, customer dissatisfaction, and unfavorable publicity. The other examples of the risks are identified and assessed at the Department of Education Program of several other BGs, which usually involves such as Schools, including students, teacher, assistant, parents, education staff of the garden. Some of BGs in Australia have also 
General Risk Assessment for Schools for the community and education program on tour or excursion, such as Melbourne BG, Royal Botanic Gardens (RBG) Victoria, Botanic gardens and Centennial Parklands (Centennial Parklands, The Royal BG Sydney, The Australian BG Mount Annan and The Blue Mountains BG, Mt Tomah) [11, 12, 13]. Whereas BGs in UK have also Risk Assessment for Schools, for instance RBG Edinburgh, Kew BG, Ventnor BG and University of Leicester BG and Attenborough Arboretum at UK [14, 15, 16]. The kind of general risk at those BG include fire, high winds, slip at glasshouse path, pond and water features, animal stings, bites and scratches, vehicle, weather (rain, lightening, wind, food allergies, plant allergies, injury by plant material, injury by activity equipment, lost child.

\section{Control Action Plan of Risk}

After the assessment, prevention and mitigation of identified risks are conducted, control action plan should be done with explain the type/form of plan, person or Unit in charge, time target, ongoing monitoring and kind of information and communication of the plan. There are 5 stages uncover a universal pattern in most conservation activity namely avoids sources, detect, block, respond and recover [17]. On the other hand, according to [18], three general methods of control of risk management are eliminate the source of the risk, establish a barrier between the source of the risk and the object/collection, and act on the agent responsible for the risk.

Routine works/activities related with plant collection in the garden mean of target time is for year-round. Whereas, the target time for information and communication that need to deliver depends on the type of the information needed. For the information which could be done in a week, then the target time is one week. However, for information needed is year-round, then the target time of the information and communication is also year-round period. The example of control action plan of risk 3.e. (Visitors or staff of the garden get accident) are conducting pruning of harmful branches, cut down dead tree, communication and coordination related with the activity, intensive control to the visitor access and put up the safety sign in the proper location or give the safety brochure to the visitors. The Unit in charge of the activities is Collection Maintenance Unit, which target time of the plan is year-round. The information needed include results of the monitoring report of the plant collection condition and the plan of pruning/cut off the collection, which be targeted weekly.

\section{CONCLUSION}

The identified risks of plant collections management of a botanic gardens are specific and could be different from one to other BGs. From 16 identified risks related with plant collection procedure at Bogor BG, 13 of those are on the level of Likelihood 3 or $50 \%$ probability or above and the impact level of the risks higher than 3 or significant. The control and action plan to prevent the risks are very urgent to be conducted immediately. The prevention of the risks even become most priority for the highest level of probability and impact, which in relation to human safety and loss of plant collection/database. In general, existing control of the identified risks has been prepared or available including the staff, procedure, equipment, tools and supervision. Many risks should be preventive by more communication, coordination, work appropriately and as procedure. Therefore, strict and on time control and supervision are still needed to be conducted with more detail and routine according to the designated schedule. In the future time, other risks should also be identified and assessed including the process of exploration and collection plant material at the original habitat, education program and other garden's services, as well as for the possibility of invasive plants as garden collection.

\section{REFERENCES}

[1] Botanic Gardens 2011. (Presidential Decree of the Republic of Indonesia Number 93) (in Indonesian)

[2] R. S. W. Jackson and L. A. Sutherland. International Agenda for Botanic Gardens in Conservation. London, UK: Botanic Gardens Conservation International, 2000.

[3] S. Sharrock, compiler. Global Strategy for plant conservation, A guide to the GSPC All the targets, objectives and facts. London, UK: Botanic Gardens Conservation International. 2012 .

[4] (2020) BGCI website. [Online]. Available: https://www.bgci.org/about/about-botanic\%20garden

[5] Control Action Plan of Internal Government Control System (RTP SPIP), Division of Ex Situ Plant Conservation, Center for Plant Conservation and Botanic Garden-LIPI, Indonesia, No II/2017, 2017

[6] Issues and Action Plan, Christchurch Botanic Gardens Management Plan, 23. Living Collection, New Zealand, 2017

[7] Risk management-Principles and guidelines, International Standard, ISO 31000, First Edition 2009-11-15, 2009.

[8] P. E. Hulme, "Addressing the threat to biodiversity from botanic gardens," Trends in Ecology and Evolution, vol.26, no. 4, pp. 168-174, 2011

[9] C. E. Husby, H. Liu and S. H. Reichard, "Weed risk assessment for botanic garden decision making," in Proc. of the $4^{\text {th }}$ Global Botanic Gardens Congress, 2010, pp 1-8

[10] Department of Agriculture and Fisheries. Biosecurity Queensland. Invasive plant risk assessment: Hiptage benghalensis. The State of Queensland: Department of Employment Economic Development and Innovation; 2011.

[11] Safety Guidelines for Education Outdoors Risk Register, Department of Education and Training. State of Victoria, Australia, 2019

[12] Child Safety During School Excursions. Royal Botanic Gardens Cranbourne Risk/ Benefit Statement. Royal Botanic Gardens Cranbourne, Victoria, Australia, 2013

[13] Excursion Risk Assessment for School Excursions and Community Programs, Department of Education and Communities, Botanic Gardens and Centennial Parklands (BGCP), Australia, 2006

[14] RBGE General Risk Assessment for Schools, Department of Education, Royal Botanic Garden Edunburgh, UK, 2016

[15] Health and Safety Risk Assessment, Royal Botanic Garden Kew, UK, Ref No 2-16, 2017

[16] School Visits Risk Assessment, University of Leicester BG and Attenborough Arboretum. University of Leicester, UK, 2017

[17] S. Michalski, "An overall framework for preventive conservation and remedial conservation," Working Group 17, Lighting and Climate Control. ICOM Committee for Conservation, Vol II, 1990, pp. 589-591

[18] R. Waller, "Preventive Conservation Planning for Large and Diverse Collections," In Preservation of Collections: Assessment, E, and Mitigation Strategies. Preprints of the June 10-11, 1996, Workshop. Washington, D. C. : American Institute for Conservation of Historic and Artistic Works, 1996. 
APPENDIX 1. THE PREVENTION AND MITIGATIONOF RISKS AT THE NURSERY UNIT

\begin{tabular}{|c|c|c|c|c|c|c|}
\hline No & Identified Risk & Existing Control & Gap & Internal Prevention & External Prevention & Mitigation \\
\hline 1.a. & $\begin{array}{l}\text { Plant material } \\
\text { from } \\
\text { exploration } \\
\text { could not be } \\
\text { handled and } \\
\text { damage } \\
\text { condition }\end{array}$ & $\begin{array}{l}\text { - Available staff, } \\
\text { Supporting equipment, } \\
\text { Procedure, Supervision }\end{array}$ & $\begin{array}{l}\text { Not optimal in } \\
\text { handling the plant } \\
\text { material }\end{array}$ & $\begin{array}{l}\text { Asking the staff to handle } \\
\text { the plant material just after } \\
\text { arriving at the garden }\end{array}$ & $\begin{array}{l}\text { Coordination with plant } \\
\text { collector and other } \\
\text { related staff/persons; } \\
\text { Develop human } \\
\text { skill/knowledge in } \\
\text { maintenance and } \\
\text { packing of plant } \\
\text { material at the field }\end{array}$ & $\begin{array}{l}\text { Communication and } \\
\text { coordination with } \\
\text { related staff/persons }\end{array}$ \\
\hline 1.b. & $\begin{array}{l}\text { Plant material } \\
\text { could not grow } \\
\text { well after being } \\
\text { handled } \\
\end{array}$ & $\begin{array}{l}\text { - Available staff, } \\
\text { Supporting equipment, } \\
\text { Procedure, Supervision }\end{array}$ & $\begin{array}{l}\text { Maintenance of } \\
\text { the plant material } \\
\text { is not as } \\
\text { procedure }\end{array}$ & $\begin{array}{l}\text { - Separate the plant material } \\
\text { according to the condition }\end{array}$ & $\begin{array}{l}\text { Coordination with plant } \\
\text { collector and other } \\
\text { related staff/persons }\end{array}$ & $\begin{array}{l}\text { - Conduct special } \\
\text { treatment to plant } \\
\text { material at the critical } \\
\text { condition } \\
\end{array}$ \\
\hline 1.c. & $\begin{array}{l}\text { Data of the } \\
\text { plant material } \\
\text { is disorganized }\end{array}$ & $\begin{array}{l}\text { - Available staff, } \\
\text { Collection database, } \\
\text { Procedure, Supporting } \\
\text { equipment/tools, } \\
\text { Supervision }\end{array}$ & $\begin{array}{l}\text { Labelling and } \\
\text { other data } \\
\text { compiling and } \\
\text { coordination is } \\
\text { done/ organize } \\
\text { inappropriate }\end{array}$ & $\begin{array}{l}\text { - Put the label safely/tight/ } \\
\text { appropriate, Re-checked all } \\
\text { data at all different } \\
\text { procedures }\end{array}$ & $\begin{array}{l}\text { Communication and } \\
\text { coordination in fill in } \\
\text { the data with } \\
\text { collector/staff at } \\
\text { different Unit }\end{array}$ & $\begin{array}{l}\text { Communication, } \\
\text { coordination with } \\
\text { related staff, Re- } \\
\text { checked during } \\
\text { working with all data }\end{array}$ \\
\hline 1.d & $\begin{array}{l}\text { Plant materials } \\
\text { grow not } \\
\text { optimal at the } \\
\text { Nursery }\end{array}$ & $\begin{array}{l}\text { - Available staff, } \\
\text { Supporting equipment, } \\
\text { Procedure, Supervision }\end{array}$ & $\begin{array}{l}\text { Maintenance of } \\
\text { plant is not as } \\
\text { procedure/ } \\
\text { inappropriate }\end{array}$ & $\begin{array}{l}\text { - Routine of plant fertilizing, } \\
\text { planting the collection at the } \\
\text { proper area, Pest and disease } \\
\text { protection, }\end{array}$ & - & $\begin{array}{l}\text { Do maintenance of } \\
\text { plant collection as } \\
\text { procedure, Tight } \\
\text { supervision and } \\
\text { communication }\end{array}$ \\
\hline $2 . \mathrm{a}$ & $\begin{array}{l}\text { Data is not } \\
\text { complete }\end{array}$ & $\begin{array}{l}\text { - Available staff, } \\
\text { Collection database, } \\
\text { Procedure, Information } \\
\text { data form }\end{array}$ & $\begin{array}{l}\text { Fill the } \\
\text { information data } \\
\text { form } \\
\text { incompletely }\end{array}$ & $\begin{array}{l}\text { - Prepare information menu } \\
\text { according to the needs, fill } \\
\text { the information data form } \\
\text { completely as procedure }\end{array}$ & $\begin{array}{l}\text { Inform/ communication } \\
\text { to all related staff the } \\
\text { complete information } \\
\text { needed to be reported }\end{array}$ & $\begin{array}{l}\text { Asking incomplete } \\
\text { data information/ } \\
\text { Coordination with } \\
\text { plant collector or } \\
\text { other related staff }\end{array}$ \\
\hline 2.b. & $\begin{array}{l}\text { Data of plant } \\
\text { collection is } \\
\text { not registered }\end{array}$ & $\begin{array}{l}\text { - Available staff, } \\
\text { supporting equipment, } \\
\text { procedure and } \\
\text { supervision }\end{array}$ & $\begin{array}{l}\text { Need more } \\
\text { coordination, } \\
\text { Data safety is not } \\
\text { appropriate }\end{array}$ & $\begin{array}{l}\text { - Not forget and do the job } \\
\text { as procedure, } \\
\text {-Ask to make back up } \\
\text { document/raw data/file }\end{array}$ & - & $\begin{array}{l}\text { - Make back up file/ } \\
\text { document }\end{array}$ \\
\hline 2.c & $\begin{array}{l}\text { The change of } \\
\text { plant name data } \\
\text { has not yet } \\
\text { been recorded }\end{array}$ & $\begin{array}{l}\text { - Available staff, } \\
\text { Supporting equipment, } \\
\text { Procedure, Supervision }\end{array}$ & $\begin{array}{l}\text { Do the job not as } \\
\text { procedure }\end{array}$ & $\begin{array}{l}\text { - Write down or fill the form } \\
\text { of the name change } \\
\text { manually or digitally }\end{array}$ & - & $\begin{array}{l}\text { Coordination with } \\
\text { plant identification } \\
\text { staff }\end{array}$ \\
\hline 2.d & $\begin{array}{l}\text { Data is lost/ } \\
\text { unavailable or } \\
\text { damage }\end{array}$ & $\begin{array}{l}\text { - Available staff, It } \\
\text { System, Document } \\
\text { manual/ procedure }\end{array}$ & $\begin{array}{l}\text { Data safety is } \\
\text { inappropriate }\end{array}$ & $\begin{array}{l}\text { Remind the staff, make back } \\
\text { up file, make document/ files }\end{array}$ & - & $\begin{array}{l}\text { File back-up, Data is } \\
\text { protected at secure } \\
\text { server }\end{array}$ \\
\hline 2.e. & $\begin{array}{l}\text { Information } \\
\text { regarding the } \\
\text { data of plant } \\
\text { collection is } \\
\text { not valid }\end{array}$ & $\begin{array}{l}\text { - Available staff, } \\
\text { Supporting equipment, } \\
\text { Procedure, Supervision }\end{array}$ & $\begin{array}{l}\text { Do the job not as } \\
\text { procedure/ } \\
\text { inappropriate }\end{array}$ & $\begin{array}{l}\text { - Avoid / Rechecked the } \\
\text { invalid data with the plant, } \\
\text { Process the data with much } \\
\text { detail }\end{array}$ & $\begin{array}{l}\text { Communication and } \\
\text { coordination in fill in } \\
\text { the data with } \\
\text { collector/staff at } \\
\text { different Unit }\end{array}$ & $\begin{array}{l}\text { Coordination with } \\
\text { plant identification } \\
\text { staff or staff at other } \\
\text { Units }\end{array}$ \\
\hline $2 . f$ & $\begin{array}{l}\text { The map of the } \\
\text { plant collection } \\
\text { in the garden is } \\
\text { not accurate }\end{array}$ & $\begin{array}{l}\text { - Available staff, } \\
\text { Supporting equipment, } \\
\text { Procedure, Supervision }\end{array}$ & $\begin{array}{l}\text { The map is not } \\
\text { supported with } \\
\text { accurate data }\end{array}$ & $\begin{array}{l}\text { - Avoid inaccurate data } \\
\text { during working in the field, } \\
\text { Process the data from the } \\
\text { survey with much detail }\end{array}$ & $\begin{array}{l}\text { Maintenance and } \\
\text { replace the } \\
\text { inappropriate equipment } \\
\text { for the collection survey }\end{array}$ & $\begin{array}{l}\text { Process the data } \\
\text { correctly an in much } \\
\text { detail before make the } \\
\text { map }\end{array}$ \\
\hline
\end{tabular}




\begin{tabular}{|c|c|c|c|c|c|c|}
\hline 3.a. & $\begin{array}{l}\text { The plant } \\
\text { condition is not } \\
\text { healthy }\end{array}$ & $\begin{array}{l}\text { - Available staff, } \\
\text { procedure, Supervision, } \\
\text { Conduct the plant } \\
\text { maintenance }\end{array}$ & $\begin{array}{l}\text { Maintenance of } \\
\text { plant is not as } \\
\text { procedure/ } \\
\text { inappropriate }\end{array}$ & $\begin{array}{l}\text { - Routine of plant fertilizing, } \\
\text { planting the collection at the } \\
\text { proper area, Pest and disease } \\
\text { protection, Addition of } \\
\text { competent human resources }\end{array}$ & - & $\begin{array}{l}\text { Do maintenance of } \\
\text { plant collection as } \\
\text { procedure, Tight } \\
\text { supervision and } \\
\text { communication }\end{array}$ \\
\hline 3.b. & $\begin{array}{l}\text { The plant } \\
\text { condition is } \\
\text { drying in the } \\
\text { garden }\end{array}$ & $\begin{array}{l}\text { - Available staff, } \\
\text { Supporting equipment, } \\
\text { Procedure, Supervision }\end{array}$ & $\begin{array}{l}\text { Maintenance of } \\
\text { plant is not as } \\
\text { procedure/ } \\
\text { inappropriate }\end{array}$ & $\begin{array}{l}\text { Routine in plant controlling } \\
\text { and watering, especially } \\
\text { during dry season }\end{array}$ & - & $\begin{array}{l}\text { Do maintenance of } \\
\text { plant collection as } \\
\text { procedure, Tight } \\
\text { supervision and } \\
\text { communication }\end{array}$ \\
\hline 3.c. & $\begin{array}{l}\text { The plant } \\
\text { collection is } \\
\text { died }\end{array}$ & $\begin{array}{l}\text { - Available staff, } \\
\text { procedure, Supervision, } \\
\text { Conduct the plant } \\
\text { maintenance }\end{array}$ & $\begin{array}{l}\text { Maintenance of } \\
\text { plant is not as } \\
\text { procedure/ } \\
\text { inappropriate; } \\
\text { Due to lightening } \\
\text { attack or animal/ } \\
\text { human } \\
\text { disturbance }\end{array}$ & $\begin{array}{l}\text { - Routine of plant fertilizing, } \\
\text { planting the collection at the } \\
\text { proper area, Pest and disease } \\
\text { protection, Addition of } \\
\text { competent human resources }\end{array}$ & $\begin{array}{l}\text { Coordination with } \\
\text { related person/ } \\
\text { institution }\end{array}$ & $\begin{array}{l}\text { Do maintenance of } \\
\text { plant collection as } \\
\text { procedure, Tight } \\
\text { supervision and } \\
\text { communication, } \\
\text { Construct suitable } \\
\text { fence at surrounding } \\
\text { of plant, Back up } \\
\text { plant material at the } \\
\text { nursery }\end{array}$ \\
\hline 3.d. & $\begin{array}{l}\text { The tree/ } \\
\text { branches fall } \\
\text { down }\end{array}$ & $\begin{array}{l}\text { - Available equipment, } \\
\text { staff team for plant } \\
\text { safety monitoring/ } \\
\text { supervision, procedure } \\
\text { in maintenance of plants }\end{array}$ & $\begin{array}{l}\text { Fall down tree/ } \\
\text { branches due to } \\
\text { climate/ nature }\end{array}$ & $\begin{array}{l}\text { - Conduct detail plant } \\
\text { healthy monitoring } \\
\text { - Handling harmful } \\
\text { plant/tree on time/not late }\end{array}$ & $\begin{array}{l}\text { Coordination in } \\
\text { handling the victim }\end{array}$ & $\begin{array}{l}\text { Handling collections } \\
\text { that harmful to fall } \\
\text { down appropriately }\end{array}$ \\
\hline 3.e. & $\begin{array}{l}\text { Visitors or staff } \\
\text { of the garden } \\
\text { get accident }\end{array}$ & $\begin{array}{l}\text { - Available staff, } \\
\text { equipment, procedure } \\
\text { and coordination for } \\
\text { pruning and other safety } \\
\text { job }\end{array}$ & $\begin{array}{l}\text { The work is not } \\
\text { done with the } \\
\text { detail procedure }\end{array}$ & $\begin{array}{l}\text { - Conduct detail and routine } \\
\text { control, pruning dry/harmful } \\
\text { branches, cut down dead tree } \\
\text { and coordination of all } \\
\text { related staff for safety works }\end{array}$ & $\begin{array}{l}\text { Conduct more intensive } \\
\text { supervision for visitor } \\
\text { access and coordination } \\
\text { in handling the victims }\end{array}$ & $\begin{array}{l}\text { Make, inform to } \\
\text { visitors and put up } \\
\text { safety signs at the } \\
\text { proper locations or } \\
\text { safety brochures }\end{array}$ \\
\hline 3.f. & $\begin{array}{l}\text { Accident } \\
\text { during working }\end{array}$ & $\begin{array}{l}\text { - Available staff, safety } \\
\text { tools, procedure and } \\
\text { supervision }\end{array}$ & $\begin{array}{l}\text { Lack of risk } \\
\text { awareness }\end{array}$ & $\begin{array}{l}\text { Develop human resource } \\
\text { capacity, use safety tools, } \\
\text { maintaining equipment and } \\
\text { tools in detail and routine, } \\
\text { change the inappropriate } \\
\text { equipment and tools }\end{array}$ & $\begin{array}{l}\text { Take the victims to } \\
\text { hospital }\end{array}$ & $\begin{array}{l}\text { Preparing first aid tool } \\
\text { and medicines, put up } \\
\text { safety signs at the } \\
\text { proper locations }\end{array}$ \\
\hline
\end{tabular}

